\title{
Migration Policy, Labor Immigration and Economic Growth: Qualitative Analysis of Correlations and Interaction Scenarios
}

\author{
Huong Le Thi Mai, Hung Tran Van, Denis Ushakov
}

\begin{abstract}
The aim of our research is to use the data on the correlation between national migration policy, economic value of labor immigration and economic growth of the today's EU member so that to define the possible directions and scenarios in modernization of both national and international regulation of the migration processes in the region.

This work also measures the indicators of national migration policy adequacy of the $\mathrm{EU}$ members in relation to the demands of both globalizing world economy and local socioeconomic priorities. The author confirms there exists a mutual relation between the adequacy of a national migration policy and economic value of labor migration for the economic progress. Core strategies and potential threats to future development of national economic systems of these countries are also outlined in the context of global migratory processes.

The offered here article also tests the hypothesis concerning the role of labor imigration in the dynamics of GDP. Other hypotheses posed here concern: reducing economic role of labor immigration for the GDP dynamics; inefficiency of the unified migration rules for all $\mathrm{EU}$ members which were introduced as an instrument for modernization of regional migration policies and levelling of the positions of very different countries.
\end{abstract}

Keywords: migration policy; international labor migration; national migration strategy; unification of migration rules; the European Union.

\section{INTRODUCTION AND METHODOLOGY OF THE STUDY}

The central issue of any migration policy is maximization of the economic value from migration, economic return from the use of foreign labor resources and ideally - under the simultaneous reduction of the accompanying losses in both short and long terms. Taking into account the current dynamics and the key trends in labor migration overall, the analysis of the EU migration policies allows outlining the following directions in modernization of the system of state regulation over immigration processes: stimulating the inflow of intellectual and highly qualified labor migrants into the EU; encouraging business and investment migration; intensive development of seasonal labor migration; making the family reunion migration system

Revised Version Manuscript Received on 16 September, 2019.

* Correspondence Author

Huong Le Thi Mai, Ho Chi Minh University of Technology and Education, Ho Chi Minh City, Vietnam

Hung Tran Van, Vietnam National University of Forestry, Dong Nai Province, Vietnam

Denis Ushakov (corresponding author), International college, Suan Sunandha Rajabhat University, Bangkok, Thailand e-mail: denis.us@ssru.ac.th more rational; certain limitations in granting the refugee status; counteracting against illegal labor migration.

Assessment of the adequacy of the national migration regimes in the today's EU members (actually, EU-28 + Turkey) has been carried on the basis of testing the migration regime in each state using the following parameters (see Table 1).

Table 1. Parameters for testing the migration regimes of the EU countries (made by co-authors)

Tested parameter

The migration regime of the country has more than one type of residence permit and more than one type of work permit

If a foreigner already has a residence permit, does it grant access to the national labor market?

Access to the national labor market for foreigners could be open only provided there are both residence permit and work permit

Are there official visas for seasonal work in the country?

Are there an option and a separate procedure to get a green card?

If a foreigner has a residence permit, does he/she get the right to buy real estate?

Family reunion right can be granted on the basis of work permit only (without any additional requirements, like certain amount of migrant's wage)

Are there requirements as to the minimum wage of a labor migrant for the start of a family reunion procedure?

Work permit is tied to a specific employer, but not to a specific type of activity

\begin{tabular}{l|l}
3 & 0
\end{tabular}




\begin{tabular}{|l|c|c|}
\hline $\begin{array}{l}\text { Is it possible to get a work permit for longer } \\
\text { than 1 year? }\end{array}$ & 3 & 0 \\
\hline $\begin{array}{l}\text { Can work permit be prolonged? (Without the } \\
\text { necessity to get a new document) }\end{array}$ & 4 & 0 \\
\hline $\begin{array}{l}\text { There is an exact requirement as to the } \\
\text { minimum wage for getting work permit }\end{array}$ & 0 & 5 \\
\hline $\begin{array}{l}\text { Work permit stems from qualification of an } \\
\text { applicant but not the work sector }\end{array}$ & 0 & 5 \\
\hline $\begin{array}{l}\text { All foreign students have the right for further } \\
\text { employment in the country and thus - for } \\
\text { changing their student visa to work permit }\end{array}$ & 3 & 0 \\
\hline $\begin{array}{l}\text { Students have the right for part-time } \\
\text { employment (combining studies with work) }\end{array}$ & 5 & 0 \\
\hline $\begin{array}{l}\text { Migration policy of the country specifically } \\
\text { mentions quotas for foreign labor migrants }\end{array}$ & 0 & 2 \\
\hline $\begin{array}{l}\text { Do citizens of other EU countries have to pass } \\
\text { registration and get work permit to start } \\
\text { working in this country? }\end{array}$ & 0 & 3 \\
\hline $\begin{array}{l}\text { Does the migration policy of the country } \\
\text { migrants that are not citizens of any EU } \\
\text { country but are temporary staying on the } \\
\text { territory of the EU? }\end{array}$ & 0 & 2 \\
\hline $\begin{array}{l}\text { Does the migration policy of the country } \\
\text { officially have quotas for foreign migrants } \\
\text { incoming on the family reunion programmes? }\end{array}$ & 0 & 5 \\
\hline
\end{tabular}

\begin{tabular}{|l|c|c|}
\hline $\begin{array}{l}\text { Does the migration policy of the country } \\
\text { officially have quotas for qualified labor } \\
\text { migrants? }\end{array}$ & 0 & 5 \\
\hline $\begin{array}{l}\text { Does the migration policy of the country } \\
\text { officially prioritizes the countries with which } \\
\text { it has bilateral agreements of cooperation? }\end{array}$ & 0 & 5 \\
\hline $\begin{array}{l}\text { Does the country have agreements on } \\
\text { migration cooperation with the countries } \\
\text { outside EU? }\end{array}$ & 5 & 0 \\
\hline $\begin{array}{l}\text { Is there a publicly acknowledged problem with } \\
\text { foreign laborers' discrimination in the } \\
\text { country? }\end{array}$ & 0 & 10 \\
\hline $\begin{array}{l}\text { Can the ownership of a commercial enterprise } \\
\text { (self-employment) be the basis for getting a } \\
\text { work permit in the country? }\end{array}$ & 5 & 0 \\
\hline
\end{tabular}

The sum of all scores (see the table above) can be understood as the level of adequacy of the migration regime of a specific European state.

\section{ADEQUACY OF THE NATIONAL MIGRATION POLICIES OF THE EU COUNTRIES}

In order to get all these answers and results we have used statistical and descriptive information from the expert groups of the European Union and also data from the national authorities responsible for regulation migration in the EU-28 and also in Turkey $[1,2,3,4,7,9,16,17]$. The final results are presented in Table 2 .

Table 2. Adequacy of the national migration policies of the EU countries + Turkey (made by co-authors)

\begin{tabular}{|c|c|c|c|c|c|}
\hline$\#$ & Countries & $\begin{array}{l}\text { The final indicator } \\
\text { of adequacy }\end{array}$ & \# & Countries & $\begin{array}{c}\text { The final indicator of } \\
\text { adequacy }\end{array}$ \\
\hline 1 & Germany & 92 & 16 & Turkey & 51 \\
\hline 2 & France & 80 & 17 & Malta & 49 \\
\hline 3 & Poland & 67 & 18 & Greece & 46 \\
\hline 4 & Czech Rep. & 66 & 19 & Slovenia & 46 \\
\hline 5 & Ireland & 66 & 20 & Spain & 46 \\
\hline 6 & UK & 62 & 21 & Slovakia & 43 \\
\hline 7 & Latvia & 59 & 22 & Austria & 41 \\
\hline 8 & Portugal & 58 & 23 & Estonia & 40 \\
\hline 9 & Finland & 56 & 24 & Lithuania & 37 \\
\hline 10 & Luxemburg & 56 & 25 & Hungary & 33 \\
\hline
\end{tabular}




\begin{tabular}{|c|l|c|c|l|c|}
\hline 11 & Netherlands & 56 & 26 & Croatia & 32 \\
\hline 12 & Bulgaria & 55 & 27 & Cyprus & 32 \\
\hline 13 & Denmark & 52 & 28 & Belgium & 29 \\
\hline 14 & Norway & 52 & 29 & Romania & $\mathbf{5 1}$ \\
\hline 15 & Italy & 47 & & $\begin{array}{l}\text { Average in the } \\
\text { EU-28 + Turkey }\end{array}$ & \\
\hline
\end{tabular}

Therefore, as the table above shows, the most adequate to the current economic dynamics in Europe are the migration policies of Germany, France and Poland. At the same time, in Romania, Belgium and Cyprus migration policies are the least adequate ones as per the requirements of the ongoing economic progress. Thus, policies of the latter three require urgent modernization and reforms.

\section{ECONOMIC GROWTH AND THE ECONOMIC VALUE OF LABOR IMMIGRATION TO THE EU COUNTRIES}

The next stage is comparing the indicators of economic value of labor immigration with the calculated criteria of the migration policy adequacy. Table 3 presents the indicators of economic value of labor migration as well as the indicators of GDP annual growth (since it is one of the most important criteria of the economic progress). All indicators are presented for the period since 2007 till 2018.

Applying the function of correlation we can now determine to what extent was the growth/fall of the economic value of labor immigration to the EU countries predetermined by the growth/fall of the national GDP (see Table 4).

Table 3. Indicators of the economic value of labor migration (column A) and annual growth of GDP (column B) in the EU-28 + Turkey, 2007 to 2018

\begin{tabular}{|c|c|c|c|c|c|c|c|c|c|c|c|c|c|}
\hline & \multirow[t]{2}{*}{ Country $^{1}$} & \multicolumn{2}{|c|}{2007} & \multicolumn{2}{|c|}{2008} & \multicolumn{2}{|c|}{2009} & \multicolumn{2}{|c|}{2010} & \multicolumn{2}{|c|}{2015} & \multicolumn{2}{|c|}{2018} \\
\hline & & A & B & A & B & $\mathrm{A}$ & B & A & B & A & B & $\mathrm{A}$ & B \\
\hline 1 & Denmark & 40 & 3,53 & 20 & $\begin{array}{c}0,4 \\
7\end{array}$ & 30 & 2,3 & 75 & 3,39 & 45 & $-0,78$ & 65 & 1,39 \\
\hline 2 & Austria & 45 & 3,67 & 30 & $\begin{array}{c}1,6 \\
9\end{array}$ & 45 & 2,59 & 80 & 3,67 & 30 & 1,44 & 40 & 1,77 \\
\hline 3 & Ireland & 35 & $\begin{array}{c}10,6 \\
5\end{array}$ & 15 & $\begin{array}{c}5,4 \\
2\end{array}$ & 35 & 4,2 & 65 & 5,51 & 50 & $-2,1$ & 55 & -1 \\
\hline 4 & Italy & 65 & 0,45 & 40 & $\begin{array}{c}1,7 \\
3\end{array}$ & 10 & 2,2 & 35 & $-1,15$ & 10 & 1,72 & 45 & $-2,36$ \\
\hline 5 & Finland & 25 & 5,32 & 25 & $\begin{array}{c}1,8 \\
3\end{array}$ & 10 & 4,12 & 30 & 4,41 & 20 & 0,29 & 90 & 3,36 \\
\hline 6 & Cyprus & 40 & 2,09 & 10 & $\begin{array}{c}4,2 \\
2\end{array}$ & 10 & 4,13 & 35 & 3,63 & 35 & 1,3 & 65 & $-2,4$ \\
\hline 7 & Greece & 35 & 4,48 & 10 & $\begin{array}{c}3,4 \\
4\end{array}$ & 0 & 4,37 & 40 & 5,51 & 35 & $-0,25$ & 75 & $-4,95$ \\
\hline 8 & Croatia & 30 & 3,75 & 10 & $\begin{array}{c}4,8 \\
8\end{array}$ & 20 & 4,13 & 0 & 4,94 & 65 & 2,08 & 60 & $-2,27$ \\
\hline 9 & Spain & 35 & 5,05 & 10 & $\begin{array}{c}2,7 \\
1\end{array}$ & 30 & 3,26 & 10 & 4,08 & 55 & 0,89 & 45 & $-0,21$ \\
\hline 10 & Germany & 60 & 3,06 & 55 & $\begin{array}{c}0,0 \\
1\end{array}$ & 10 & 1,16 & 35 & 3,7 & 10 & 1,08 & 10 & 4,01 \\
\hline 11 & Netherlands & 60 & 3,94 & 0 & 0,0 & 25 & 2,24 & 15 & 3,39 & 20 & 1,8 & 55 & 1,53 \\
\hline
\end{tabular}

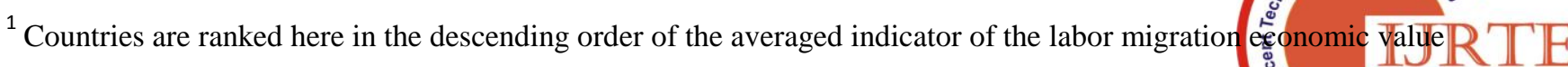


Migration Policy, Labor Immigration and Economic Growth: Qualitative Analysis of Correlations and Interaction Scenarios

\begin{tabular}{|c|c|c|c|c|c|c|c|c|c|c|c|c|c|}
\hline & & & & & 8 & & & & & & & & \\
\hline 12 & Norway & 0 & 3,25 & 10 & 1,5 & 25 & 3,96 & 65 & 2,3 & 25 & 0,07 & 45 & 0,48 \\
\hline 13 & Czech Rep. & 30 & 4,19 & 30 & $\begin{array}{c}2,1 \\
5\end{array}$ & 20 & 4,74 & 40 & 7,02 & 20 & 3,1 & 65 & 2,47 \\
\hline 14 & Luxemburg & 10 & 8,44 & 15 & $\begin{array}{c}4,0 \\
9\end{array}$ & 15 & 4,37 & 50 & 4,94 & 20 & $-0,73$ & 55 & 3,1 \\
\hline 15 & Portugal & 35 & 3,92 & 15 & 2,5 & 0 & 2,2 & 35 & 1,45 & 10 & 0,1 & 45 & 1,67 \\
\hline 16 & Malta & 5 & 2,81 & 45 & $-0,5$ & 0 & 2,22 & 10 & 4,36 & 0 & 2,71 & 65 & 1 \\
\hline 17 & France & 40 & 1,3 & 0 & $\begin{array}{c}2,2 \\
3\end{array}$ & 0 & 2,21 & 35 & 0,1 & 15 & 1,72 & 30 & 0,01 \\
\hline 18 & Slovenia & 25 & 3,83 & 0 & 4,4 & 20 & 5,85 & 20 & 3,59 & 10 & 1,38 & 45 & $-2,5$ \\
\hline 19 & Hungary & 25 & 4,51 & 0 & 4,8 & 10 & 3,9 & 25 & 0,89 & 5 & 1,26 & 35 & $-1,7$ \\
\hline 20 & Estonia & 30 & 9,7 & 10 & $\begin{array}{c}6,5 \\
6\end{array}$ & 0 & 6,34 & 35 & 10,1 & 10 & $-4,15$ & 10 & 2,56 \\
\hline 21 & Romania & 10 & 5,03 & 10 & $\begin{array}{c}9,1 \\
2\end{array}$ & 20 & 8,72 & 5 & 7,86 & 30 & $-0,94$ & 20 & 0,35 \\
\hline 22 & Bulgaria & 0 & 4,7 & 15 & 6,7 & 20 & 6,5 & 10 & 6,2 & 25 & 0,4 & 20 & 0,6 \\
\hline 23 & Slovakia & 10 & 4,58 & 0 & $\begin{array}{c}5,0 \\
6\end{array}$ & 30 & 8,35 & 20 & 5,75 & 5 & 4,18 & 20 & 1,8 \\
\hline 24 & Belgium & 10 & 1,36 & 0 & $\begin{array}{c}3,2 \\
7\end{array}$ & 0 & 2,67 & 0 & 0,99 & 0 & 2,34 & 75 & $-0,14$ \\
\hline 25 & UK & 0 & 4,36 & 10 & 2,3 & 0 & 3,17 & 35 & 2,76 & 10 & $-0,76$ & 10 & 1,66 \\
\hline 26 & Turkey & 5 & 6,77 & 10 & $\begin{array}{c}6,1 \\
6\end{array}$ & 0 & 9,36 & 10 & 6,89 & 0 & 0,66 & 20 & 9,16 \\
\hline 27 & Latvia & 0 & 6,47 & 20 & $\begin{array}{c}8,6 \\
8\end{array}$ & 0 & $\begin{array}{c}12,2 \\
3\end{array}$ & 0 & $-4,24$ & 10 & $-0,34$ & 0 & 5 \\
\hline 28 & Lithuania & 20 & 6,86 & 0 & $\begin{array}{c}7,3 \\
5\end{array}$ & 10 & 7,84 & 0 & 2,93 & 0 & 1,33 & 0 & 3,7 \\
\hline 29 & Poland & 10 & 4,26 & 0 & $\begin{array}{c}1,4 \\
4\end{array}$ & 0 & 5,34 & 0 & 6,23 & 0 & 5,13 & 10 & 3,88 \\
\hline
\end{tabular}

Table 4. Correlation between economic growth and the economic value of labor immigration to the EU countries

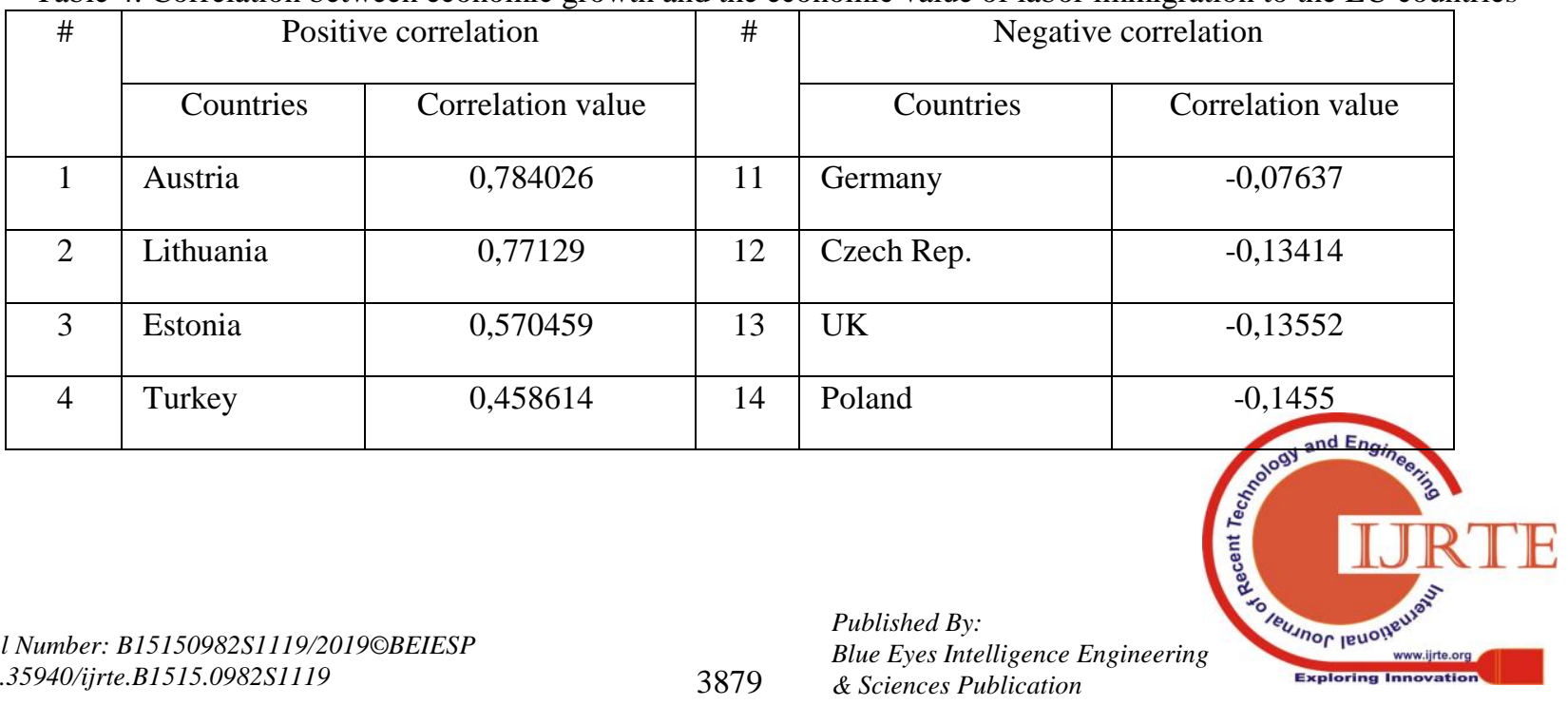




\begin{tabular}{|c|c|c|c|c|c|}
\hline 5 & Slovakia & 0,40552 & 15 & Luxemburg & $-0,17691$ \\
\hline 6 & Denmark & 0,324341 & 16 & Norway & $-0,22081$ \\
\hline 7 & Netherlands & 0,258408 & 17 & France & $-0,29272$ \\
\hline 8 & Portugal & 0,233983 & 18 & Ireland & $-0,39402$ \\
\hline 9 & Latvia & 0,135021 & 19 & Bulgaria & $-0,48583$ \\
\hline \multirow[t]{10}{*}{10} & Finland & 0,060657 & 20 & Italy & $-0,49804$ \\
\hline & & & 21 & Spain & $-0,58006$ \\
\hline & & & 22 & Hungary & $-0,60733$ \\
\hline & & & 23 & Slovenia & $-0,652$ \\
\hline & & & 24 & Malta & $-0,71216$ \\
\hline & & & 25 & Romania & $-0,71328$ \\
\hline & & & 26 & Greece & $-0,72605$ \\
\hline & & & 27 & Belgium & $-0,77152$ \\
\hline & & & 28 & Croatia & $-0,8159$ \\
\hline & & & 29 & Cyprus & $-0,91219$ \\
\hline
\end{tabular}

As seen in Table 4, the situation with migration policies and migration dynamics inside the EU cannot be called homogeneous. 10 states demonstrate a positive correlation, which means that in these countries the growth of economic value of the labor immigration has been predetermined (to larger or lesser extent) by their economic growth. At the same time, in the majority of the EU members we can observe a negative correlation: the economic value of

Table 5. The indicators of correlation between economic growth rates and economic value of immigration in the EU countries (column A) and the adequacy of the migration policy (column B), as of 2018

\begin{tabular}{|c|l|c|c|c|l|c|c|}
\hline \multirow{2}{*}{$\#$} & \multicolumn{3}{|c|}{ Positive correlation } & \multirow{2}{*}{$\#$} & \multicolumn{2}{c|}{ Negative correlation } \\
\cline { 2 - 5 } \cline { 7 - 8 } & Countries & A & B & & Countries & A & B \\
\hline 1 & Austria & 0,784026 & 41 & 11 & Germany & $-0,07637$ & 92 \\
\hline 2 & Lithuania & 0,77129 & 37 & 12 & Czech Rep. & $-0,13414$ & 66 \\
\hline 3 & Estonia & 0,570459 & 40 & 13 & UK & $-0,13552$ & 62 \\
\hline 4 & Turkey & 0,458614 & 51 & 14 & Poland & $-0,1455$ & 67 \\
\hline 5 & Slovakia & 0,40552 & 43 & 15 & Luxemburg & $-0,17691$ & 56 \\
\hline 6 & Denmark & 0,324341 & 52 & 16 & Norway & $-0,22081$ & 52 \\
\hline 7 & Netherlands & 0,258408 & 56 & 17 & France & $-0,29272$ & 80 \\
\hline 8 & Portugal & 0,233983 & 58 & 18 & Ireland & $-0,39402$ & 66 \\
\hline 9 & Latvia & 0,135021 & 59 & 19 & Bulgaria & $-0,48583$ & 55 \\
\hline
\end{tabular}

labor immigration was growing in the years of restrained economic growth or the years when GDP rate was on a fall. In 12 EU countries the dependence between their economic growth and the economic value of labor immigration in them can be traced rather obviously (though this dependence can be either positive, or negative). 


\begin{tabular}{|c|c|c|c|c|c|c|c|}
\hline 10 & Finland & 0,060657 & 56 & 20 & Italy & $-0,49804$ & 51 \\
\hline & & & & 21 & Spain & $-0,58006$ & 46 \\
\hline & & & & 22 & Hungary & $-0,60733$ & 33 \\
\hline & & & & 23 & Slovenia & $-0,652$ & 46 \\
\hline & & & & 24 & Malta & $-0,71216$ & 49 \\
\hline & & & & 25 & Romania & $-0,71328$ & 28 \\
\hline & & & & 26 & Greece & $-0,72605$ & 46 \\
\hline & & & & 27 & Belgium & $-0,77152$ & 29 \\
\hline & & & & 28 & Croatia & $-0,8159$ & 32 \\
\hline & & & & 29 & Cyprus & $-0,91219$ & 32 \\
\hline
\end{tabular}

Table 5 presents the results of the comparative analysis for the indicators of economic value of the labor immigration with the indicators of economic growth and those of the adequacy of their national economic policy.

We can observe a rather obvious regularity here which is describing the behavior of the indicator of economic value of the labor immigration in its dependence from the trends and achievements of the national migration policies in the EU countries (the correlation between these two indicators is $-0,79)$.

Thus, with a high enough probability (0.79) we can assume that:

- with growth of national migration policy adequacy in the EU countries, the economic value of labor immigration for GDP rates will be going down;

- and if the national migration policy adequacy will go down, it will cause higher economic value of labor migration for the changing GDP.

This statistically determined regularity thus allows us to:

- prove empirically the economic efficiency of adequate migration policies in Europe. Truly efficient national migration policy relaxes the dependence of the economic value of labor immigration from the macroeconomic indicators of the country. In other words, adequate migration policy can really be an efficient instrument of migration regulation in particular and of state regulation of national economy in general;

- explain that adequate migration policy is, on the one hand, reducing the economic value of labor immigration for macroeconomic dynamics, but on the other - it makes macroeconomic development more predictable and regulated.

Since there are obviously several variants of combining the degree of national migration policy adequacy with the economic value of labor immigration in the analyzed EU countries, we can assume there can be also several possible scenarios of implementing national migration policies under the conditions of multivector development of the macroeconomic indicators of the states in question.

As Figure 1 clearly shows, we can differentiate between the two groups of possible scenarios - soft ones (1.1,
$2.1,3.1,4.1)$ and more radical ones $(1.2,2.2,3.2,4.2)$. It is quite obvious that the first one have rather weak migration policies (in terms of its adequacy) and minor economic value of labor immigration revealed. Thus, the first quadrant is called "Mutually beneficial union" - this scenario can be implemented when the adequacy of a national migration policy fits the natural value of labor immigration within the overall economic system of a country (when both the migration policy and the immigration itself are adequate to the current dynamics of the economic indicators).

When the economic value of labor immigration starts to grow while rigidness of the national migration policy remains at the same level, a country can shift to the next quadrant, metaphorically called "Spendthrift landlady". Under this scenario, positive consequences from economic growth of the whole country would be distributed between foreign laborers, therefore, further effects from economic progress would be scattered between the countries - donors of labor migration.

Lowering economic value of labor immigration (which is a natural reaction of the market to unnecessary generosity (see the previous quadrant) and inefficiency) triggers the shift to the third scenario - "Economical economy". In the course of this scenario implementation the national economic system is supposed to adapt to a new production structure which includes engagement of both national and foreign labor force.

Finally, tightening of the national migration policy (as a natural consequence from restructuring of the national labor market) would eventually lead the country to the last scenario and quadrant - "Nationalization of the labor market". In the course of its implementation rigidity of state regulation over labor migration would be growing while economic value of labor immigration would remain to be quite low.

If we consider the union of several countries (the EU in our case), it becomes rather obvious that unification of migration rules would not be helpful in terms of modernization of regional migration policies. More, the unification would not really smooth the differences between the members of the union and definitely would not solve regional problems related to efficiency of the migration processes' regulation. 
In Figure 2 all 28 EU members + Turkey are located in the quadrants they belong to. To place them on this system of axes we have used the previously calculated data on the adequacy of their migration policies as well as on the economic value of labor immigration.

\section{Conclusions}

Looking at Figure 2, we can surely state that no homogeneity or even similarity is observed within the group of European countries in question: all countries are relatively equally distributed between all possible scenarios, both radical and soft ones.

For this very reason we can state that unification of migration policies of, say, Norway and Bulgaria would never make these countries closer on this system of axes. In simple terms, implementation of one common immigration scenario is simply impossible! At the same time, unification of economic values of labor immigration within the EU-28 seems to be also impossible due to serious differences in the development level and the structure of national economic systems, their rates of labor productivity and other macroeconomic indicators. Thus, we can conclude that the EU members should coordinate their efforts and tools of migration policies in the context of national migration systems' modernization, taking into account both planned and forecasted indicators of the economic value of labor immigration/emigration. For all these countries without exception the key objective, when it comes to regulation of labor migration, should be prevention of the most radical scenarios' development.

As Figure 2 clearly shows, France, UK and Poland are dangerously close to diving deep into the most radical scenarios of foreign laborers' discrimination. At the same time, Germany, Ireland and Denmark are following the scenario of nearly absolute administering of migration. Austria and Cyprus are gradually moving to the situation of uncontrolled immigration. Finally, Belgium, Latvia and Romania are currently surviving through the most depressing and crisis phase, with its low quality and same low adequacy of the national migration policies.

Relatively stable positions are being maintained by the countries of Southern and Northern Europe and also by some of the EU "newbies" (Malta, Slovenia, Slovakia and Estonia).

Our research on migration dynamics and peculiarities in formation and implementation of migration policies in the EU countries demonstrates not only heterogeneity of the latter (which actually leads to additional problems with intraregional labor migration and supranational infrastructure of migration regulation for the whole $\mathrm{EU}$ as a unique socioeconomic project) but also the complexity of combining the political instruments of migration regulation with purely economic ones. Another acute problem in this regard is the necessity to reorient the whole system of axes in migration regulation so that to include the new priorities into it - national and/or regional self-sufficiency, economic security and saving unique cultural identities.

\section{REFERENCES}

[1] Economist Intelligence Unit (2014). Estimating potential labor shortage and supply in the European Economic Area. A report for Home Office Advisory Committee.
[2] Estruch-Puertas, E. \& Zupi, M. (2013). Assessment of data sources and methodology development for measuring foreign labor requirements in the Russian Federation. Working Paper.

[3] Arkhipov, A., Ushakov, D. (2018). Functional effectiveness and modern mechanisms for national urban systems globalization: The case of Russia. In: E-Planning and Collaboration: Concepts, Methodologies, Tools, and Applications, IGI-global.

[4] International Labor Organization. European Migration Network (2018) Satisfying labor demand through migration. Synthesis report.

[5] Regional determinants of localization of recent immigrants across OECD regions (2018). International Migration Outlook, SOPEMI (2009). Managing migration - are quotas and numerical limits the solution?

[6] International Organization for Migration (IOM). (2017). Migration, employment and labor market integration policies in the European Union. IOM LINET.

[7] Jacoby, T. (2013). Selecting for integration - What role for a point system? (Policy Brief). German Marshall Fund of the United States.

[8] Kahanec, M. \& Zimmermann, K. (2011). High-skilled immigration policy in Europe. Institute for the Study of Labor (IZA).

[9] Labour shortages and migration policy (2019). Edited by Platonova A. and Urso G. International Organization of Migration, Belgium.

[10] Neugart, M. \& Schomann, K. (2002). Employment outlooks: Why forecast the labor market and for whom? Discussion paper FS I 02-206 Wissenschaftszentrum Berlin für Sozialforschung.

[11] Labor shortages and the need for immigrants: A review of recent studies (2009). OECD, Paris.

[12] Ushakov, D., Rubinskaya, E. (2018). Reforming of the state immigration policy in the context of globalization: On the example of Russia. In: Immigration and the Current Social, Political, and Economic Climate: Breakthroughs in Research and Practice. IGI-global.

[13] Papademetriou, D. G. et al. (2008). Hybrid immigrant-selection system The next generation of economic migration schemes. Migration Policy Institute.

[14] Ruhs, M. \& Anderson, B. (eds) (2010). Who needs migrant workers? Migration Policy Institute.

[15] Papademetriou, D. G. et al. Talent in the 21st century economy (2008). Migration Policy Institute.

[16] Ushakov, D. (2015). Labor immigration in dynamic of European Union's national economic progress: macroeconomic analysis and basic indicators. Actual Problems of Economics, 3.

[17] Ushakov, D., Chich-Jen, S. (2018). Global economy urbanization and urban economy globalization: Forms, factors, results. In: E-Planning and Collaboration: Concepts, Methodologies, Tools, and Applications, IGI-global. 